\title{
Faize Alternatif Bir Finansman Aracı Olarak Karz-ı Hasen Yerine Zekât
}

\section{Zakät Instead of Qarz-ı Hasan As Alternative Finance Tool to Interest}

\author{
Enver Osman KAAN \\ Dr. Öğr. Üyesi, Marmara Üniversitesi Illahiyat Fakültesi, İslam Hukuku Anabilim Dalı \\ Assist. Prof., Marmara University, Faculty of Theology, Department of Islamic Law \\ İstanbul, Turkey \\ enoskaan73@gmail.com \\ orcid.org/0000-0003-4087-1129
}

\begin{abstract}
Makale Bilgisi / Article Information

$\begin{array}{ll}\text { Makale Türü / Article Types } & \text { : Araştırma Makalesi / Research Article } \\ \text { Geliş Tarihi / Received } & : 4 \text { Ekim / October } 2021 \\ \text { Kabul Tarihi / Accepted } & : 12 \text { Aralık / December } 2021 \\ \text { Yayın Tarihi / Published } & : 15 \text { Aralık / December } 2021 \\ \text { Yayın Sezonu / Pub Date Season } & \text { : Aralık / December } \\ \text { Cilt / Volume: } 8 \text { - Sayı / Issue: } 2 \text { - Sayfa / Pages: 605-621 } \\ \text { Atıf / Cite as }\end{array}$

Atıf / Cite as

Kaan, Enver Osman. "Faize Alternatif Bir Finansman Aracı Olarak Karz-ı Hasen Yerine Zekât". Bülent Ecevit Üniversitesi Ilahiyat Fakültesi Dergisi 8/2 (2021), 605-621.

Doi: 10.33460/beuifd.1004299

Intihal / Plagiarism

Bu makale, en az iki hakem tarafından incelendi ve intihal içermediği teyit edildi.

This article has been reviewed by at least two referees and scanned via a plagiarism software.

Yayın Hakkı / Copyright ${ }^{\circ}$

CC BY-NC-ND 4.0 | Zonguldak Bülent Ecevit Üniversitesi, İlahiyat Fakültesi tarafından yayınlanmıştır. Telif ve yayın hakları, Creative Commons Atıf-Gayri Ticari-Türetilemez 4.0 lisansının hüküm ve koşullarına tabidir.

CC BY-NC-ND 4.0 | Published by Zonguldak Bulent Ecevit University. Copyrights are subjected to the terms and conditions of a Creative Commons Attribution-NonCommercial-No Derivatives License 4.0.
\end{abstract}

Öz: Zekât, İslam ibadet esaslarından biri olarak farz kılınmıştır. Faiz ise Allah'a ve resulüne harp ilan etmek kadar ağır bir işlem görülerek haram kılınmıştır. Kur'an'ı Kerim'de faiz ile zekât karşılaştırılarak; verilen faizin Allah katında artmayacağı, buna karşın Allah'ın rızası gözetilerek verilen zekâtın kat kat artacağı beyan edilmiştir. Hâlbuki faiz bir borç işlemidir, borç işleminde verilenin geri alınması söz konusudur. Zekât ise geri alınmamak üzere verilen maldır. Kur'an'ı Kerim'de borç vermekle ilgili kullanılan karz-ı hasen kavramı "güzel borç" anlamına gelir. Dolayısıyla, karz-ı hasen de bir borç işlemi olduğuna göre bu kavramın faiz ile karşılaştırmalı olarak ele alınmaması dikkat çekmektedir. Zekât ile faiz ekonomik, siyasi, sosyal ve ahlaki boyutları olan iki önemli kavramdır. Bu iki kavramı sadece ekonomi penceresinden değerlendirmek orantısız bilgi karşılaştırmasına neden olmakta ve faizin karz-ı hasen yerine zekât ile mukayesesinin anlaşılması zorlaşmaktadır. İşte makalede faiz ile karz-ı hasen kavramının neden karşılaştırmalı ele alınmadığının izahı yapılmaya çalışılacaktır. Ayrıca faiz, verilen borcun fazlasıyla geri alınması yani verilen paranın artması demektir. Zekât ise, malın bir kısmını geri almamak üzere başkasına vermek yani maldan eksilt- 
me yapmaktır. Görünüşte asıl artma faizde yaşandığı halde, ayette artış vurgusunun zekâtta yapılmasının piyasaya yansıması üzerinde durulacaktır.

Anahtar Kelimeler: İslam Hukuku, Karz-ı Hasen, Zekât, Faiz, Finansman

\begin{abstract}
Zakät has been made obligatory as one of the principles of Islamic worship. Interest, on the other hand, was rendered unlawful by being treated as harshly as declaring war against Allah and His Messenger. By comparing interest and zakāt in the Qur'ān; It has been declared that the interest given will not increase in the sight of Allah, whereas the zakät given by observing Allah's consent will increase many times over. However, interest is a debit transaction, it is possible to get back what is given in the debit transaction. Zakät is the property that is given to not be taken back. The concept of qarz-ı hasan, which is used for lending in the Qur'ān, means "beautiful loan". Certainly, zakät and interest are two important concepts that have economic, political, social and moral dimensions. Evaluating these two concepts only from the perspective of economics causes information asymmetry and it is really difficult to understand the comparison of interest with zakät instead of qarż-ı hasan. Therefore, since qarz-ı hasan is a debit transaction, it would be expected to consider this concept in comparison with interest. However, this was not done. One of the purposes of this article will be to explain why the concept of interest and qarz-I hasan is not discussed comparatively. In addition, riba (interest) means that the debit that is given interest is paid back, that is, the money given increases. Zakāt, on the other hand, is to give a part of the property to someone else without getting it back, that is, to make a decrease in the property. Although the real increase seemingly is a result of the interest transaction, the reflection of the real increase in zakāt in the verse will be emphasized in the commercial life, market conditions and economic system.
\end{abstract}

Key Words: Islamic Law, al-Qarẓ al-Hasan, Zakāt, Interest, Financing

\title{
Giriş
}

İslam'ın onayladığı iktisadi sistem ile kapitalist sistemin ayrıldığı en önemli noktalardan biri faiz meselesidir. Diğer semavi dinlerde de bulunmasına rağmen faiz yasağının güçlü bir şekilde günümüze taşınmasında en büyük paya sahip olan İslam dini olduğu bilinmektedir. Kur'an'da faiz kesin bir dille yasaklanmış, faiz yiyenlerin Allah'a ve resulüne savaş açmak kadar tehlikeli bir işe giriştikleri açıkça ifade edilmiştir. ${ }^{1}$

İslam dini faizi yasaklamakla yetinmemiş zekâtı, ihtiyaç sahibine finans kaynağı olan temel ibadetlerden biri kabul etmiştir. Faiz ile zekâtın karşılaştıııldığı ayette şöyle buyurulmuştur:

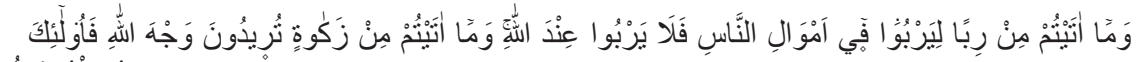

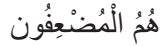

1 el-Bakara 2/279. 
"Insanların mallarında artış olsun diye verdiğiniz herhangi bir faiz, Allah katında artmaz. Allah'ın rızasını isteyerek verdiğiniz zekâta gelince, işte zekâtı veren o kimseler, evet onlar kat kat arttıranlardır."2

Faiz bir borç ilişkisidir. Zekât ise ibadet anlamı taşıyan karşılıksız vergidir. Faizin alternatifi olarak neden yine bir borç ilişkisi olan karz-ı hasen gösterilmediği, onun yerine zekâtın gösterildiği meselesinin açıklığa kavuşturulması makalenin hedeflerinden birisidir.

Ayrıca faiz, verilen borç karşılığında alınan fazlalıktır. Zekât ise nisaba ulaşan malın bir kısmını ihtiyaç sahibine vermektir. Burada reel anlamda fazlalığın meydana geldiği yer faiz olmasına rağmen asıl artmanın verilen zekâtta gerçekleşmesinin analizi yapılmaya çalışılacaktır.

Zekâtın faize alternatif olmasını rahat anlayabilmek için faizin toplumlar üzerindeki yıkıcı izlerini tarihi bilgilerden faydalanarak görmek gerekir. Bu sebeple önce faizin tarih boyunca farklı toplumlardaki seyrini vermek faydalı olacaktır.

\section{Tarih Boyunca Faiz}

Tarih boyunca din ile iktisat arasında kadim ve arkaik bir bağ olmuştur. Adam Smith bunun sebebini "para bir inanç meselesidir" (All money is a matter of belief) ${ }^{3}$ diye ifade ederken Max Weber kapitali besleyen gıdanın inanç olduğu şeklinde izah etmeye çalışmıştır. Nitekim toplumların dini hayatında tapınaklar tanrıların yeryüzündeki ikamet yerleri olarak tasarlandıkları gibi iktisadi hayatlarında da ekonominin merkezi olma görevini üstlenmişler ve finansal ihtiyaçların kurumsal bağlamda ele alındığı yerler olmuşlardır. Daha sonra tapınakların yerini bankalar almıştır. Böylece ekonominin gelişimi tapınaklardan devlete, oradan da bankalar yoluyla piyasaya kaymıştır. ${ }^{5}$

Günümüz banka modeli ortaya çıkana $k^{2} a r^{6}$ finans sektörünün izlerini Sümer, Babil ve Asurlularda sürmek gerekir. Bu medeniyetler kurulmadan önce iktisadi ilişkilerin bulunduğu iddia edilse de o döneme ait yeterli bilgiye sahip değiliz. İktisadi ilişkiler hakkında ilk bilgiler Urukagina ${ }^{7}, \mathrm{Ur}^{-\mathrm{Namm}^{8}}{ }^{8}$, Ana-itttuşu ${ }^{9}$,

2 Komisyon, Kur'an-ı Kerim ve Türkçe Açıklamalı Meali, (Medine: Kral Fehd Mushaf-ı Şerif Basım Kurumu, ts.), erRûm 30/39.

3 Adam Smith, The Wealth of Nation, (New York: Metalibri, 2007), 221.

4 Max Weber, The Protestant Ethic and The Spirit of Capitalism, (New York: Charles Scribner's Sons, ts), 36.

5 W.W. Hallo, God, King, and Man at Yale State and Temple Economy in the Ancient Near East, (Leuven: Department Orientalistiek, 1978), 31.

6 Modern banka modelinin temeli 1141 'de Paris'te VII. Louis tarafından atılmıştır. Ancak iktisat tarihçileri bankacılığın İtalya'da kurulduğu istikametinde bilgi vermektedirler.

7 Adını en eski yasa yapıcı olarak kabul edilen Lagaş kralı Urukagina (M.Ö. 2350) dan almaktadır. Bilinen en eski Sümerce hukuk metnidir. Bk. Adem Işık, "ilk Şehirler ve Yazılı Medeniyete Geçiş", Mavi Atlas, 6 (2) /2018, 29-74.

8 Ur sülalesinin ilk kralı Ur-Nammu (M.Ö. 2100) tarafından yazdııımıştır. Bk. Işık, "Yazılı Medeniyete Geçiş", 60.

9 Hem Sümerce hem Asurca kaleme alınmış bir kanundur. 
Lipit-Iştar $^{10}$, Eşnunna ${ }^{11}$ ve Hammurabi' ${ }^{12}$ yasalarından elde edilebilmektedir. Bu metinlerde servet, satım, kiralama, ödünç, faiz oranları ve işçi-işveren ilişkilerine dair maddelere rastlanılmaktadır. Özellikle Hammurabi kanunlarında faizin yasaklanması meselesi yerine, ortaya çıkardığı sosyal problemlere değinilmektedir.

Kaynaklarda Roma imparatorluğunu çöküşe götüren sebepler arasında faiz en başlarda sayılır. Özellikle İmparator Tiberius zamanında hakkında sınır dışı kararı çıkan tefeci Yahudilerin takipsizlik yüzünden kararın uygulanmaması, ileride imparatorluğun başına bela açmış ve bu Yahudiler imparatorluğun çöküşünde etkin rol oynamıştır. Roma toplumu, evlerinde içinde faizle borç vermek için ayrılmış paraların saklandığı kasalar bulundurmakta hatta damat kayınpederine verdiği borcu vaktinde alamazsa faiziyle geri istemekteydi. Bu durumun daha kötüsü, insanların faiz borçları sebebiyle köleleştirilmeleridir. İmparatorluğun son yıllarında imparator, ağır faiz yükü altında ezilen halktan faiz oranlarını düşürmek, faiz borcu sebebiyle köleleştirilenleri serbest bırakmak gibi tedbirlere başvurmuş olsa da imparatorluğun çöküşünü durduramamıştır. ${ }^{13}$

Antik Yunan'da faiz (tokos) oranları filozofları isyan ettirecek kadar yüksekti. Bu filozofların başında Platon gelir. ${ }^{14} \mathrm{O}$, faiz almayı ahlak dışı bir davranış olarak tanımlamıştır. Öğrencisi Aristo ise mübadele aracı olan paranın asıl amacından uzaklaştırılarak kullanılmasının eşyanın tabiatına ve adalete aykırı olduğunu ifade ederek faizi eleştirmiştir. ${ }^{15}$

Hinduizm'in kutsal metinlerinden özellikle Smitrilerde faiz çeşitlerine ve borç işlemlerine dair düzenlemelere yer verilir. Hinduizm'deki kast sistemi faiz işlemlerine bile yansımıştır. Vaisyalara, faiz (kusida) ile hayatlarını sürdürmelerine izin verilirken, Brahmanlar ve Kşatriyalar'a yasaklanmış, faiz oranları, yapılan işin çetinliğine göre değişir hale gelmiştir. Yasal faiz oranı \%15 iken, deniz aşırı yapılan ticarette $\% 40$, orman aşılarak yapılan ticarette ise $\% 120$ lere kadar çıktığı olmuştur. Kast sistemindeki tabaka farklılıkları faiz oranlarının tespitinde bile etkili olmuştur. Vaisyalar borçlanırken \%48 oranı belirlenirken, Sudralar'da bu oran $\% 60$ 'larda seyretmiştir. ${ }^{16}$

Budizm'de faizli borç ilişkilerinden daha ziyade insanın içine düştüğü onur kırıcı durum üzerinde durulmaktadır. Budist anlayışta "vergi oranının düşük olması üretimi, faizsiz borç verilmesi ise ticareti geliştirir" anlayışı yaygındır. ${ }^{17}$

10 M.Ö. 1920 yılında İsin ailesinin kralı Lipit-Iştar tarafından Sümerce yazılımış kanun metnidir.

11 Kral Daduşa tarafından yazıldığı tahmin edilen bu kanun metni Akkadça yazıımış ilk metindir.

12 Hammurabi kanunları Mezopotamya'da ortaya çıkan tarihin en eski korunmuş metnidir. M.Ö. 1760 yıllarında yazılmıştır.

13 S.M. Goodson, A History of Central Banking and the Enslavement of Mankind, (London: Black Haouse Publishing, 2014), 67-69.

14 F. Neumark, İktisadi Düşünce Tarihi, çeviri: Ahmet Ali Özeken, (İstanbul: iÜ Yayınları, 1983), 28-30; Feridun Ergin, Para ve Faiz Teorileri, (istanbul: Beta Basım, 1983), 133.

15 Mehmet Saraç, Faiz Teorisini Yeniden Düşünmek, (İstanbul: Iktisat Yayınları, 2017$), 33$.

16 Ustaoğlu- Incekara (ed.), Faiz Meselesi Tarihte Örnek Uygulamalar, 97-107.

17 Ustaoğlu- Incekara (ed.), Faiz Meselesi Tarihte Örnek Uygulamalar, 118-124. 
Yahudilikte faiz, "yılan ısırığına (neshek)" benzetilmesine ve sosyo-ekonomik dengeleri zehirlediği iddia edilmesine rağmen bu yasak sadece Yahudiler ile sınırlandırılarak tahrif edilmiştir. Tevrat'ta geçen ayetlerde "Halkım arasındaki birine para verirsen, borç veren biri gibi davranmayacak; ondan faiz almayacaksın"18 "Hemşehrine ödünç verdiğin -para olsun, yiyecek olsun ya da üzerine faiz eklenebilen her türlü şeyden- faiz almayacaksın"19 "Bir kardeşin yoksullaşır, muhtaç duruma düşerse ona yardım etmelisin. Aranızda kalan bir yabancı ya da konuk gibi yaşadığında ondan faiz ve kâr alma. Tanrıdan kork ki, kardeşin yanında yaşamını sürdürebilsin. Ona faizle para vermeyeceksin. Ödünç verdiğin yiyecekten kâr almayacaksın."20

Hristiyanlıkta da faiz yasaklanmıştır, ancak Yahudilerin aksine faiz yasağı herkese uygulanmıştır. İncil'de "Geri alacağınızı umduğunuz kişilere ödünç verirseniz, bu size ne övgü kazandırır? Günahkârlar bile verdiklerini geri almak koşuluyla günahkârlara ödünç verirler."21 Ancak kutsal kitabı Thomas Aquinas ve Martin Luther $^{22}$ gibi tarihselci (historical critisizm) okumaya tâbi tutanlar, yasağın asıl amacının aşırı faiz alınarak insanların sömürülmesini önlemek olduğu yorumunu yaparak faizi ikiye ayırmışlardır. Onlara göre faizin birinci kısmı paranın kullanımı karşılığı ödenen miktar (usury), ikinci kısmı ise paradan mahrum kalınan süre karşılığında hak edilen gelir (interest) dir. ${ }^{23}$ Uzun müddet Hristiyanlıkta riayet edilen faiz yasağı ilk olarak Jean Calvin tarafından delinmiştir. Faiz yasağını eleştiren Calvin, üretim ile tüketim faizini birbirinden ayırarak tüketim faizinde niteliksel bir ayırıma gitmiştir. Calvin, makul faiz seviyesi gözetildiği sürece faizin teolojik anlamda bir sorun teşkil etmeyeceğini iddia ederek kapitalizmin temellerini atmıştır. ${ }^{24}$

Faizi en sert bir şekilde yasaklayan ve bu yasağı günümüze kadar taşıyan İslam dini olmuştur. Bununla birlikte İlhanlı hükümdarı Gazan Han dönemi gibi ağır cezaların konulduğu dönemlerde bile mahkemelerde faiz davalarına rastlanılmaktadır. Osmanlı döneminde faiz hassasiyeti açısından iki iktisadi yapı ortaya çıkmıştır. Birincisi faiz hassasiyeti gütmeyen sarraflar ve tefecilerdir. İkincisi ise para vakıflarıdır. Para vakıfları özellikle bidaa, mudarabe, murabaha, muamele-i şer'iyye ve bey' bil-istiğlâl gibi ürünler ile işlemlerini yürütmüşlerdir. Osmanlı'da para vakıfları sarraf ve tefecilerin uyguladığı ağır faiz oranları altında ezilenleri kurtarmak amacıyla bir alternatif kurum olarak ortaya çıkmış ve Molla Hüsrev (öl. 1480), Ahi Çelebi, İbn Kemal, Ebussuud Efendi (öl. 1574), Bali Efendi (öl. 1553) gibi âlimler tarafından desteklenmiştir. Buna karşın Çivizade (öl. 1547), İmam Birgivi

18 Study Bible, (New York: Harper Collins, 2006), Mısırdan Çıkış, 22/25.

19 Tesniye, 23/19

20 Levililer, $25 / 35-37$

21 Luka $6 / 34$

22 Ustaoğlu- Incekara (ed.), Faiz Meselesi Tarihte Örnek Uygulamalar, 194-208.

23 Ustaoğlu- İncekara (ed.), Faiz Meselesi Tarihte Örnek Uygulamalar, 8.

24 Neumark, Iktisadi Düşünce Tarihi, 60; Ergin, Para ve Faiz Teorileri, 138. 
(öl. 1573) gibi âlimler faiz endişesiyle para vakıflarının yasaklanması için mücadele etmişlerdir. Para vakıflarını savunan âlimler zaruret, maslahat ve örfü gerekçe göstermişlerdir. Nitekim para vakıfları zaman içinde küçük esnafın fonlanmasından belediye hizmetlerine kadar birçok alanda finansman ihtiyacını karşılayan bir kurum haline gelmiştir. Para vakıfları fonlama araçları olarak karz (borç verme) bidaa (aldığı borcu çalıştırıp kârının bir kısmı ile geri vermesi), mudarabe (sermayeemek ortaklığı) gibi ürünlerin yanında tartışmalı ürünler olan muamele-i şer'iyye ve bey' bi'l-istiğlal gibi ürünler de kullanmışlardır. Özellikle son iki ürün şerî̂ hile kapsamında değerlendirilerek, Yahudilerin avlanma yasağını delmek için ağlarını Cumartesi atmaları ancak avlanmayı Pazar yapmalarına veya içyağından menfaat sağlama yasağına riayet ediyor gözükerek eritip satmalarına benzetilerek ağır eleştirilere tâbi tutulmuşlardır. ${ }^{25}$

\section{Faiz Yasağı ve Borç Verme İşlemi (Karz)}

Faiz (riba), literatürde borç olarak verilen parayı yahut malı süresi sonunda belirlenen oranda fazlalıkla ya da borç ilişkisinden doğan alacağa vade tanıyıp fazlalıkla geri almanın adıdır. ${ }^{26}$ Bu tanımdan da anlaşılacağı gibi İslam fıkhında faiz, ayette zikredilen vadeye dayanan riba'n-nesîe ve hadiste zikredilen mislî mallar üzerinde cereyan eden riba'l-fadl olmak üzere iki çeşittir. ${ }^{27}$ Makalede faiz denilince riba'n-nesîe yani vâde faizi kastedilmektedir.

Karz-ı Hasen güzel borç demektir. ${ }^{28}$ Borç anlamına gelen karz, ${ }_{,}^{29}$ literatürde yararlanıldığında tüketilen mislî yani piyasada benzeri bulunan malın emsali geri alınmak üzere verilmesidir. ${ }^{30}$

Görüldüğü gibi hem faiz hem de karz, borç verme işlemi olduğu için aralarında yakın ilişki vardır. Bazı kaynaklarımızda verilen borcun bir menfaate bağlanması "ribe'l-kuruz" olarak adlandırılması ve yasaklanması faiz ile karz arasındaki yakın ilişkiyi ortaya koyan bir tamlamadır. ${ }^{31}$ Ancak faizde verilen borç için belli bir süre tanınır. Borç veren o süre bitmeden alacağını geri isteyemez. Belirlenen süre bitince de alacağını yine belirlenen oranda fazlasıyla geri alır. Karz işleminde ne süre vardır ne de fazlalık bulunur. ${ }^{32}$ Sadece Malikî mezhebinde va'd bağlayıcı kabul edildiği için, karzda ileri sürülen vadenin de bağlayıcı olacağı kabul

25 Ustaoğlu- İncekara (ed.), Faiz Meselesi Tarihte Örnek Uygulamalar, 275-292.

26 İsmail Özsoy, "Faiz", Türkiye Diyanet Vakfı İslam Ansiklopedisi (İstanbul: TDV Yayınları, 1995), 12/110-126.

27 Ebu Hasen Ali b. Ebi Bekir el-Merğinani, el-Hidaye, Tahkik: Ahmed eş-Şehade, (İstanbul: Mizan Basım Yayın, 2020), 3/149;

28 Komisyon, el-Mu'cemu'l-vesîd, 727.

29 Karzın TBK'daki tanımı şöyledir: "Karz bir akiddir ki onunla ödünç veren, bir miktar paranın yahut diğer bir mislî şeyin mülkiyetini ödünç alan kimseye nakil ve bu kimse dahi buna karşı miktar ve vasıfta müsavi aynı neviden şeyleri geri vermekle mükellef olur". (md. 306)

30 H. Yunus Apaydın, “Karz”, Türkiye Diyanet Vakfı Islam Ansiklopedisi (İstanbul: TDV Yayınları, 2001), 24/520-524.

31 Nezih Hammad, Akdu'l-karz fi'ş-şeriati'l-islamiyye, (Beyrut: yy., 1991), 11.

32 Alaaddin Ebu Bekir b. Mesut el-Kâsânî, Bedâ'i'u's-sanâi' fi tertibi'ş-şerâi', (Beyrut: Daru'l-Kütübü'l-İlmiyye, 1997), 10/600; 
edilmiştir. ${ }^{33}$ Dolayısıyla borç veren istediği zaman alacağını isteme ve geri alma hakkına sahiptir. ${ }^{34}$ Çünkü borç verenin borcu için belli bir sürenin şart koşulması çoğunluk âlimlere göre bu işlemi ribe'n-nesie yani vadeli faize çevirir. Yalnız borçmenfaat ilişkisinde kullanılan كل قرض جر نفعا فهو ربا "İçinde menfaat barındıran borç faizdir" ${ }^{\prime 35}$ hadisi zayıf olduğu gerekçesiyle delil kabul edilmez. Bununla birlikte, Hz. Peygamber'in başından geçen bir olaya binaen borç alanın alacaklıya şart koşmadan aldığı borcun daha iyisini vermesi, borca ilavede bulunması ya da iyilik yapmasının faiz kapsamına girmeyeceğini söyleyebiliriz. Olay şöyledir: kendisine bir deve yavrusunu borç veren kişi devesini almaya gelince $\mathrm{Hz}$. Peygamber aynı yaşta deve verilmesini emreder fakat o yaşta deve bulunmayınca daha yaşlı ama daha pahalısının verilmesini söyler, arkasından da "en hayırlınız borcunu en güzel şekilde ödeyeninizdir" buyurur. ${ }^{36}$

Hanefiler dört yerde karz-ı hasene süre konulabileceğini söylemişlerdir. Bu yerlerin birincisi vasiyettir ki ölmeden önce birisine örneğin bir yıllığına borç verilmesini vasiyet edenin varisleri bu vasiyete aykırı hareket edemez. İkincisi, inkâr edilen borca, borcu veren belli bir süre koyduğunda bu süre bağlayıcı olur. Üçüncüsü, mahkeme kararı ile borca süre konulduğunda bağlayıcı olur. Dördüncüsü ise borçlu alacaklıyı başkasına havale ettiğinde alacaklı alacağını süresinden önce talep edemez. ${ }^{37}$

Bazı Müslüman âlimler Jean Calvin gibi çağdaş ekonomistlerden etkilenerek borç verme işlemini tüketim borcu (القروض الاستهلاكية) ve üretim borcu (القروض olarak ikiye ayırırlar. Tüketim borcu dedikleri gıda, ilaç ve barınma gibi intiyaçlar için alınan borçtur. Üretim borcu işte kullanılmak üzere arabanın veya iş alet ve edevatı için veya işçilerin maaşını ödemek için alınan borçtur. Asıl faizin tüketim faizi olduğunu ve yasaklanması gerektiğini, üretim faizinin serbest bırakılması gerektiğini iddia ederler. Hâlbuki İslam âlimleri faizi, alış-veriş faizi (ربا (الييع) ve borç faizi (ربا القرض) diye ikiye ayırsa da hükümde bir ayrıma gitmeden her ikisini de haram kabul etmişlerdir. ${ }^{38}$

Kur'an'daki karz-ı hasen ile ilgili açıklamalar borç verme işlemini kazanç aracı ve ticari faaliyet konusu olmaktan çıkarmaya yönelik teşviklerdir. ${ }^{39}$ Bu sebeple,

33 Ahmet Özdemir, "Karz Akdinin Mahiyeti ve Faizli İşlemleri Önleme Fonksiyonu," Çukurova Üniversitesi Illahiyat Fakültesi Dergisi 12 (1), 130; Abdullah Durmuş, "Fıkıhta Karz Sözleşmesinde Vade Şartının Bağlayıcılığı Meselesi”, İlâm Hukuku Araştırmaları Dergisi, sayı: 16, 2010, 315-330.

34 Vehbe Zuhayli, el-Fıkhu'l-Islâmî, (Dimeşk: Dâru'l-fikr,1989), 721.

35 Zuhayli, el-Fıkhu'I-Islâmî, 727; Keşfu'l-hafa sahibi Aclûnî bu sözün Hâris b. Ebi Üsame tarafından rivayet edildiğini ama senedinde kopukluk olduğunu ifade eder. Aclûnî, Keşfu'l-hafa ve muzilu'l-ilbas, (Beyrut: Şeriketu Şerifi'lEnsârî, 2000), 2/148.

36 Müslim, "Musakat", 117, 119; Ebu Davut, "Buyu”, 11; Tirmizi, “Buyû”, 73; Nesei,” Buyu”, 64; İbn Mace, “Ticarat", 62; Muvatta, "Buyu", 89; Darimi, "Buyu", 31.

37 Zuhayli, el-Fıkhu'I-İsâmî, 727; Abdulfettah Muhammed Ferah, et-Tevcihu'I-Istismarî li'z-zekât, (İmarat: Duba'lİslâmî, 1997), 115.

38 Salih Hamid el-Ulâ, Tevzi'ud-dahl, (Dimeşk: Yemâme, 2001), 316.

39 Özdemir, Karz Akdinin Mahiyeti ve Faizli İşlemleri Önleme Fonksiyonu, 125-145. 
karz-ı hasen yoluyla kurulan borç verme uygulamasının âtıl fonları piyasaya aktarmak gibi bir amacı olduğunu düşünmek yanlış olur. Zira bu fonlar, mudaraba, müşareke, istisna' vb. alternatif yöntemlerle ekonomiye aktarılabilir. ${ }^{40}$ Karz-ı hasen'in böyle bir fonksiyon icra etmesinin arkasında onun, kısa vadeli ve düşük tutarlı finansman ihtiyaçlarında kullanılan yardım kredisi olarak düşünülmesinin payı olduğu söylenebilir. ${ }^{41}$ Nitekim hadislerde karz-ı hasen uygulamaları ile ilgili açıklamalar da bunu göstermektedir. Örneğin bir hadiste Hz. Peygamber, İsra gecesi cennetin kapısı önünde "sadakaya karşılık on misli ama borca karşılık on sekiz misli ecir vardır" yazısını görünce Cebrail'e "borç vermek neden sadaka vermekten daha faziletlidir? diye sorduğumda O, "çünkü sadaka isteyen yanında varken de isteyebilir ama borç isteyen ihtiyacından dolayı ister" demişti. ${ }^{42}$ Burada sadaka ile karzın aynı bağlamda ele alınması finansman sağlamadaki benzerliklerini de göstermektedir.

Aslında borç işlemini haram hale getiren sürenin belirlenmesi değil verilen borcun fazlasıyla geri alınmasıdır. Nitekim şart koşulmaması kaydıyla karz-ı hasende belirlenen süreye riayet edilmesinde bir sakınca bulunmamaktadır. ${ }^{43}$ Fakat verilen borcun fazlasıyla geri alınması belirlenen süreyi de haram hale getirmektedir. ${ }^{44}$ Ayrıca borcun şahitler huzurunda yazılarak kayıt altına alınma tavsiyesi borç işleminin hukuk çerçevesinde yapılmasına işaret etmektedir. ${ }^{45}$

\section{Zekât-Faiz Karşılaştırması}

Faizli işlemleri savunanlar faize farklı gerekçeler gösterirler. Kimilerine göre faizin gerekçesi, paranın satın alma gücündeki kaybın karşılığı, kimilerine göre ise, bireyin tüketimden mahrum kalmasının mükâfatıdır. ${ }^{46}$ Bazıları faizin gerekçesini, bireyin borç verdiği parasını geri almak için beklediği sürenin tazmini ${ }^{47}$ olarak görürken, diğerleri ise eldeki paranın elde edilecek paradan daha değerli olduğu varsayımından hareketle kıymetli olana bir değer biçmek olarak sunmaktadır.

Zekât ve faiz kavramlarının kesiştiği nokta her ikisinin de insanlar arasında bir çıkar ilişkisine dayanmasıdır. Ancak zekâtta çıkar, görünürde darlık içinde olanın lehine varlıklı olanın aleyhine işlerken, faizde varlıklı olanın lehine darlık içinde olanın aleyhine işlemektedir.

Zekât ve faizde işlem para veya mallar üzerinden yürür. Ancak zekâtta verilen, dolaylı olarak geri dönerken faizde direk olarak geri döner. Şöyle ki, zekâtta veri-

\footnotetext{
40 Abdulkadir İlgen, "Para-Sermaye ve Emek bağlamında Faiz/Riba Meselesi”, Türkiye Günlüğü, 81, (Ankara: 2005), 95.

41 Mücahit Özdemir, “Karz-ı Hasen İçin Duyarlııı Artırılmalı” (Rpt. Yahya Ayyıldız), IGIAD Bülten, (Mayıs, 2019$), 14$.

42 İbn Mâce, "Sadakat", 19.

43 Mahmud Tahmaz, el-Fıkhu'l-Hanefi fi sevbihi'I-cedid, (Dımeşk: Dâru'l-kalem, 2014), 4/215.

44 Salih Hamid el-Ulâ, Tevzi'ud-dahl, 325.

45 Saraç, Faiz Teorisini Yeniden Düşünmek, 165

46 Ingiliz iktisatçı Nassau Senior'un tanımı için bkz. Tarek el-Diwany, Faiz Sorunu, çev. Mehmet Saraç, (İstanbul: İz Yayıncılık, 2011), 49.

47 Alfred Marshall'ın bu yaklaşımı için bkz. el-Diwany, Faiz Sorunu, 49.
} 
len miktar piyasaya çıkar, tüketim yoluyla üretime katkı sağlarken faizde verilen miktar piyasaya çıkması bir yana piyasada var olanı da geri alır ve üretimi tıka-

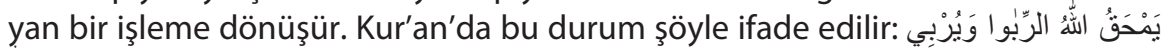
"Allah faizi tüketir, sadakaları (zekâtı) ise arttırır."48

Ayrıca faize dayalı ekonomik sistemlerde faiz oranlarının artması beraberinde tasarruf tedbirlerini getirir. Tasarruf tedbirleri tüketim harcamalarının azalması demektir. Yani bu durum mal ve hizmetlere harcanan paranın düşmesi anlamına gelir ki bu işin sonu işsizlik oranının yükselmesine kadar gider. Zekâtta ise durum tam tersidir. Zekât, zengindeki paranın fakirin eline geçmesini sağlar, eli para gören fakir çarşıya pazara gider ve alış-veriş yapar, mal ve hizmet satın alır. Böylece iş ve iş alanları çoğalır, istihdam ihtiyacı ortaya çıkar ve işsizlik oranlarında azalma meydana gelir. ${ }^{49}$

Faizde mübadele aracı ve değer ölçütü olan paraya mal muamelesi yapılır ve paradan para üretilme yoluna gidilir. Diğer bir ifadeyle borç olarak verilen paradaki potansiyel üretkenlik özelliği, borç verildiği esnada gerçek anlamda kâra dönüşmüş farz ederek fazlalık tahakkuk ettirilir. Kapitalist sistemin temelini de bu oluşturur. Zaten Latince bir kelime olan "capitale" faizli para anlamına gelmektedir. Bununla birlikte yine de kapitalist sistemde faize bu zaviyeden bakılmaz. Kapitalist sistemde faizin, paranın kiralanması karşılığında elde edilen bedel veya kullanıma arz edilen sermayenin geliri olarak tanımlanır. ${ }^{50}$ Kur'an-ı Kerim ise bunu reddeder. İlgili ayette şöyle buyurulur:

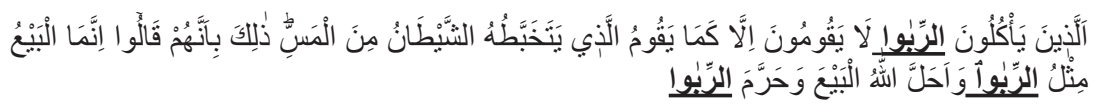

"Faiz yiyenler ancak şeytanın çarparak sersemlettiği kimse gibi kalkarlar. Bunun sebebi onların, "Alım satım da ancak faiz gibidir" demeleridir. Hâlbuki Allah alım satımı helâl, faizi ise haram kılmıştır." ${ }^{\prime 51}$

Bu ayette, faizi alış-verişe benzetmenin yanlış olduğunun altı çizilir. Çünkü alış-veriş, sonucu kâr olan bir sebeptir. Halbuki faiz sebepsiz bir sonuçtur. Bu nedenle haram kılınmıştır. Böylece zekâtın dayandığı yerin kârın sebebi olan alışveriş olduğu, faizin ise böyle bir dayanağının olmadığı anlaşılmış oluyor. Nitekim Rum suresi 39. ayette de bu hususa dikkat çekilerek şöyle buyurulur:

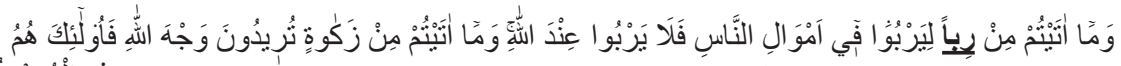
"Insanların mallarında artış olsun diye verdiğiniz faiz Allah katında artmaz. Allah'ın hoşnutluğunu isteyerek verdiğiniz zekâta gelince, işte kat kat arttıranlar onu verenlerdir. ${ }^{152}$

48 el-Bakara 2/276.

49 el-Diwany, Faiz Sorunu, 55.

50 W.L. Smith, "Monetery theorries of the rate f interest: A dynamic analysis", The Review of Economics and Stattistics 40 (1), 1958, 15-21.

51 el-Bakara 2/275.

52 er-Rum 30/39. 
Sonuçta, zekâtın ibadet olarak kabul edilmesinin arkasında, meşru yoldan elde edilen kazancın miktarı belli kısmının toplumun ihtiyaçlı kesimi ile paylaşılması yatmaktadır. Faizin yasaklanmasının arkasında ise, hiçbir şey yapmadan ihtiyaç sahibi kimselerin sırtından haksız fazla bir kazanç elde edilmesi bulunmaktadır.

\section{Faiz-Karz-ı Hasen Farklılaşması}

Çalışmanın önceki bölümlerinde görüldüğü gibi ayetlerde faiz ile zekât karşılaştırması yapılmaktadır. Hâlbuki faiz bir borç ilişkisi olması hasebiyle karz-ı hasen ile karşılaştırılması beklenirdi. Bunun sebebi; faiz risksiz bir kazançken, karz-ı hasen ise daima içinde borcun geri ödenmemesi gibi bir risk barındırmaktadır. Her ne kadar aynı risk faizde de olsa bir yerden alamadığı zaman diğer yerden alacağı fazlalıkla onu telafi edebilir. Karz-ı hasen'in telafisi ancak zekâtına saymakla mümkün olacaktır, fakat klasik görüşte bu hüküm cevaz verilen bir uygulama değildir. ${ }^{53}$ Diğer taraftan zekât, faiz gibi risksiz bir kazançtır ama burada kazanan zengin değil fakirdir. Zekâtı veren zengin ise yaptığı bu iyilik karşısında manevi haz alarak ve toplum tarafından bir şekilde ödüllendirilerek kazançlı çıkan kişidir.

Faizin karz-ı hasen ile karşılaştırılmamasının diğer bir sebebi ise, faiz işlemi bir finans işlemi olmasının yanında en dikkat çeken tarafı ahlakî yönüdür. Faiz işlemini uygulayan kişi borcunu ödeyemeyen kişiyi eskiden köleleştirmeye varacak şekilde ezebilmekteydi. ${ }^{54}$ Günümüzde icra yoluyla hesaplarına ve mallarına haciz koydurabilmektedir.

Faizin ortaya çıkmasında fon piyasalarındaki arz ve talebin etkili olduğu bir gerçektir. Aynı zamanda verimliliği yükseltmek amacıyla sermaye kullanımını artırarak üretim sürecini aktif hale getirmek de amaçlanmaktadır. Bu sebeple, bazı alimler ihtiyaç duyulan fonun enflasyon oranındaki faizle sağlanmasına cevaz vermektedirler. ${ }^{55}$ Zira enflasyonun yüksek olduğu ülkelerde paranın değerini korumak çok zor olduğu için kimse bireysel olarak karz-ı hasen yoluyla borç vermek istememektedir. ${ }^{56}$ Bununla birlikte, kurumsal olarak Pakistan'da Akhuwat Foundation gibi, Türkiye'de katılım bankaları bünyesinde, KAMPERDER, GÖNFEDER, MÜSIAD ve İKSAR gibi sivil toplum örgütlerinde karz-ı hasen sandıkları kurarak ihtiyaç sahiplerine borç verildiği bilinmektedir. ${ }^{57}$

53 Alâuddin Ebû Bekr b. Mes'ud Kâsânî, Bedâi'us-Sanâi' fî Tertîbi'ş-Şerâi', Tahkik: Ali Muhammed Muavviz, Adil Ahmed Abdulmevcûd, (Beyrut, Dâru'l-Kütüpi'l-IImiyye, ts.), 2/392; İbn Rüşd, Bidayetü'l-müctehid ve nihayetu'lmuktesıd, (Beyrut: Dâru'l-Kitabi'l-Izzi), 2/38; Ebu Zekeriyya Yahya b. Şeref en-Nevevi, Ravzatu't-Talibin, Tahkik: Adil Ahmed Abdulmevcud, Ali Muhammed Muavviz, (Beyrut: Daru'l-Kütüp-i İlmiyye, 1992), 2/51; Abdurrahman Cezîrî, Kitabu'I-Fıkh ala'I-Mezâhibi'I-Erbea, (Beyrut: Dâru'I-Kütübü'I-IImiyye, 1990), 1/548.

54 S.M. Goodson, A History of Central Banking and the Enslavement of Mankind, (London: Black Haouse Publishing, 2014), 67-69.

55 Muhammed Takî el-Osmanî, Buhûs, "Ahkâmu'I-Evrâkı'n-Nakdiyye", (Dâru'l-Kalem: Dımeşk, 2011), 166-192; Nezih Kemal Hammad, "Tagayyurâtu'n-Nukûd ve'I-Ahkâm el-Müte'allikati bihâ fi'l-Fıkhi'I-Islâmî", Mecelletü'l-Mecmai'lFıkhi'l-İslâmî, 1408/1987, III/3, 1677-1679; Bkz. Özdemir, Karz Akdinin Mahiyeti ve Faizli İşlemleri Önleme Fonksiyonu, 137-138.

56 Veli Sırım, "İslam İktisadında Yatırımların Finansmanında Karz-ı Hasen Uygulamaları”, Iğdır Üniversitesi Sosyal Bilimler Dergisi, Ek sayı, (Aralık 2019), 140-141.

57 Sırım, Karz-ı Hasen Uygulamaları, 149-156. 
Diğer taraftan dünyada meydana gelen ekonomik krizlerin çoğunun arkasında kontrolsüz ve aşırı yapılan yönetilemez borç yükü bulunmaktadır. Çoğu zaman bu borçlanma faiz enstrümanı kullanılarak yapılmaktadır. Karz-ı hasen de bir borçlanmadır ancak karz-ı hasen'in kullanıldığı yer, zekât gibi bireysel ihtiyaçların finanse edildiği yardımlaşma mekanizmasıdır. ${ }^{58}$

Burada şunu da ifade etmek gerekir ki, Müslüman toplumlarda faizli kredi işlemlerinin artmasının arkasında karz-ı hasen gibi finans sağlama araçlarının yaygınlık kazanmaması vardır. Bunun da sebebi; karşılıksız borç vermenin getireceği manevi kazanç inancının ve bilincinin azalması, enflasyonun yüksek olduğu ülkelerde paranın değerinin düşmesi ve verilen ödüncün vaktinde geri alınamaması endişesidir. ${ }^{59}$

\section{Faiz ve Zekâtın İktisadi Hayattaki Rolleri}

Çalışmanın farklı yerlerinde ifade edildiği üzere faizi savunanlar, borç verenin, borçlunun elindeki sermayesinden mahrum olmasını, sermayesini kısmen veya tamamen kaybetme riskini, borcu alanın elde edeceği kârı paylaşmasını, sermayenin zaman değeri olduğunu, likidite ihtiyacının karşılanmasını veya enflasyonun karşılığı olmasını gerekçeler arasında sayarlar. Halbuki tüm bu gerekçelerin ortaya çıkmasının sebebi yine faizin kendisidir. Zira sermayesini faiz karşılığı borç veren kendi isteğiyle sermayeden mahrum olmaktadır. Ayrıca sermayeyi elinde bulunduran borçlu kâr edebileceği gibi zarar da edebilir. Zamanla elde edilen kârın belirlenen oranda sermaye sahibiyle paylaşılması, piyasadaki likidite ihtiyacının karşılanması ve enflasyonun ortaya çıkması, sermayenin faizli borç verilmesinin doğurduğu sonuçlardır. ${ }^{60}$

Bu sonuçların bazıları olumlu görülebilir ancak faizli borç verme işleminin doğurduğu olumsuz sonuçlar olumlu sonuçlardan daha fazladır. Bunların başında yatırımların durması gelir. Razi tefsirinde faizin haram kılınma sebeplerini anlatırken kazanç yollarını tıkayacağından bahseder. Dihlevi de faizin ziraat ve sanatı öldüreceğini anlatarak faiz yasağının akli gerekçesini ortaya koymaya çalışır. ${ }^{61}$ Ünlü iktisatçılardan Thomas Culpeper 16. yüzyılda faizin insanları mesleklerinde tembelliğe sevk edeceğini, onları tefeci yapacağını ancak faiz oranlarının düşürülmesi ziraatı ve ticareti teşvik edeceğini anlatır. ${ }^{62}$

Faizin doğurduğu olumsuz sonuçlardan bir diğeri işsizlik oranlarının artmasıdır. Faiz insanları tembelliğe sevk ettiği gibi çalışma alanlarını da azaltır. Zira insanlar üretim yapmak için projeler geliştirmek yerine sermayelerini faize yatırır böylece iş alanları açılmaz ve işsizlik oranları yükselir. 1983 yılında Fransa'da

58 Saraç, Faiz Teorisini Yeniden Düşünmek, 168.

59 Özdemir, Karz Akdinin Mahiyeti ve Faizli İslemleri Önleme Fonksiyonu, 141.

60 Salih Hamid el-Ulâ, Tevzi'ud-dahl, 307.

61 Fahreddin Razi, Mefatihu'l-gayb, (Beyrut: el-Mektebe et-Ticariyye, ty.), 4/95; Şah Veliyyullah Dihlevi, Huccetullahi'lbâliğa, çeviri: Mehmet Erdoğan, (İstanbul: İz yayıncılık, 1994), 2/328.

62 Rahoman Af, Economic Doctrines of Islam, (Lahore: Islamic Publications Limited, 1980), 3/98. 
işsizlik oranı \%9,5, Birleşik Krallık'da \%14, Belçika'da \%12,8, Amerika Birleşik Devletleri'nde bu oran \%10,8 gerçekleştiğinde bunun sebebinin faiz olduğu açıklanmıştı. ${ }^{63}$ Ünlü iktisatçı Keynes işsizliğin başlıca sebebi faizdir, faiz oranlarının insanları çalışmaya sevk edecek seviyelere indirilmesi gerektiğini söylemişti. ${ }^{64}$

Faizin doğurduğu diğer olumsuz sonuçlar arasında şunlar sayılabilir; piyasada durgunluk, enflasyon, hayat pahalılığı, ekonomik istikrarsızlık ve gelir dağılımındaki adaletsizlik. ${ }^{65}$

Görüldüğü gibi faiz iktisadi hayatı mahveden bir borç işlemiyken faize alternatif olarak gösterilen zekât zengin ile fakir arasında gönül köprüleri inşa etmesinin yanı sıra reel ekonomiye katkısı sayesinde iktisadi hayatı canlandıran bir finansman kaynağı olma işlevini yerine getirmektedir.

Zekâtın iktisadi hayatla ilişkisi kelimenin etimolojik ve semantik anlamından anlaşılır. Zekât kelimesinin kök anlamında arınma olduğu gibi malda artma, ekonomik değer üretme anlamı da bulunmaktadır. ${ }^{66}$

Zekât, şer'an zengin olanın malının bir kısmını geri almamak üzere zekâtın sarf yerine vermesi olarak ${ }^{67}$ tanımlandığı halde, malın bir kısmını vererek malın eksilmesi yerine artmasının manası, geliri düşük olan sosyal kesime satın alma gücü kazandırarak onları üretici güç haline getirmesidir. Bu yaklaşım sadece İslam'da bulunmaktadır. Çünkü İslam'ın dışındaki diğer dinler ve ideolojiler dini hayat ile iktisadi hayatı ayırmışlardır. İslam zekât sayesinde dini hayat ile iktisadi hayatı birleştirmeyi başarmıştır. ${ }^{68}$

Zekât, ihtiyaç sahibine karşılıksız destek anlamına geldiği gibi nema yani büyüme ve gelişme özelliğine sahip malı olan varlıklı kişinin parasının veya genel olarak servetinin finans dünyasıyla veya piyasayla ilgisinin kesilmesini engelleme anlamı da taşır. Kur'an'da altın ve gümüşü biriktirip harcamayanların yerilmesinden ${ }^{69}$ hareketle zekâtın hedeflerinden birinin paranın âtıl kalmasını önlemek ve piyasaya hem de ulvi bir anlayışla sürülmesini sağlamak olduğu yorumu yapılabilir.

Zekâtın iktisadi hayata katkısını tüm dünyada istatistiksel verilerle göstermek ve pratik düzlemde ele almak zor gözükmektedir. Çünkü zekât Müslümanların

63 The Euroupa Year Book, (London: Europa Limited, 1983), 1/601.

64 John Maynard Keynes, The General Theory of Employment, Interest and Money, (London: Macmillan Limited, 1970), 375.

65 Salih Hamid el-Ulâ, Tevzi'ud-dahl, 344.

66 İbn Manzur, Ebi'l-Fadl Cemaleddin Muhammed b. Mukrim, Lisanu'l-arab, (Beyrut: Daru's-sadr, 1968), 358; Fîrûzâbâdî, Mecduddin Muhammed bin Yakub (öl. 817/1414), Besairu't-temyiz, ed. Muhammed Ali Neccar, (Beyrut: Daru'I-IIlmiyye, ts.) Zekât md.; Rağıp el-İsfehani, el-Müfredat, (Daru'l-Marife: Beyrut, 1999), 218.

67 Yunus Vehbi Yavuz, İslam'da Zekât Müessesesi, (Bursa: Feyiz Yayınları, 2008), 61.

68 Ali Bulaç, Türkiye'de Zekât Potansiyeli, (İstanbul, İSAV Yayınları, ts.), 131.

69 et-Tevbe $9 / 34$. 
yoğun yaşadığı birçok Müslüman ülkede verilen zekât miktarı kayıt altına alınmamaktadır. Türkiye de zekât potansiyeli kayıt altına alınmayan ülkelerdendir. ${ }^{70}$

İslam dünyasında zekât potansiyelini kayıt altına alan ülkelerin başında Malezya ve Endonezya gelmektedir. Bu iki ülke merkeze konularak yapılan araştırmalar göstermiştir ki düzenli ve disiplinli bir şekilde zekâtın verildiği toplumlarda ekonominin en büyük sorunu olan yoksulluk oranlarında ciddi oranda düşüş meydana gelmektedir. Şöyle ki; toplumun en varlıklı \%20'sinin gelirinden en yoksul gelirli \%20'sine zekât verildiğinde varlıklı kesimin geliri \%2,5 oranında azalırken yoksul kesimin gelirinin \%19 oranında arttığı görülmüştür. Yine toplumun en varlıklı \%40'nın gelirinden en yoksul gelirli \%20'sine zekât verildiğinde varlıklı kesimin geliri \%2,5 oranında azalırken yoksul kesimin geliri \%27 oranında artmıştır. Bu oranlar toplumun en varlıklı \%60'nın gelirinden en yoksul gelirli \%20 'sine zekât transfer edilmesi şeklinde değiştiğinde varlıklı kesimin gelirinin \%2,5 oranında azaldığı yoksul kesimin gelirinin ise \%33 oranında arttığı gözlemlenmiştir. ${ }^{71}$

Değişik zamanlarda yapılan araştırmalara göre Türkiye'nin zekât potansiyeli yoksulluğu ortadan kaldıracak oranda olduğunu göstermiştir. 1986-1990 yılları arasında Türkiye'nin zekât potansiyeli GSYH'ye oranı \%1,75 ile \%1,8 arasında değişmektedir. 2012-2017 yılları arasında bu oran \%2,67 ile \%2,94 arasında olmuştur. Türkiye'nin 2018 yılı zekât potansiyelinin 50 milyar dolar, 2019 yılında bu miktarın 55 milyar dolara yükseldiği ifade edilmiştir. ${ }^{72}$

Zekât mükellefleri ödemekle yükümlü oldukları oranı zekâtın sarf yerlerine ulaştırdıkları takdirde kamu bütçesinin yükü hafiflemekle kalmayacak hem gelir dağılımı ve yoksulluk göstergelerinde iyileşme meydana gelecek hem de kamu bütçesi, kamunun daha farklı ihtiyaçlarının karşılanmasında ve yatıımların yapılmasında kullanılabilecektir.

\section{Sonuç}

Faiz, ihtiyaç sahibine verilen borcun üretim sürecine girmesi beklenmeden borç verenin lehine takdir edilen fazlalığın adıdır.

Zekât, emek ve sermaye sahibinin elde ettiği kârın belli bir miktarını ayette sayılmış olan sarf yerlerinden birine vermesidir. Zekât, aslında şer'an zengin olanın yaptığı iş karşılığında toplum tarafından kendisine ödül olarak verilen kârın yine toplum ile paylaşılmasıdır.

70 Bu makale yazıldığında Türkiye'de 2021 yılında Diyanet Iş̧ıeri Başkanlığı Din Hizmetleri Genel Müdürlüğüne bağlı olarak Zekât Hizmetleri Daire Başkanlığı yeni kurulmuştu.

71 Osman Demir-Hüseyin Cevahir, Türkiye'de Potansiyel Zekât Geliri ve Zekâtın Yoksulluğu Önleyici Rolü, International Journal of Islamic Economics and Finance Studies, 2021/2, 163-182.

72 Demir-Cevahir, Islamic Studies, 165-169. 
Faiz ile zekâtın karşılaştırıldığı ayette "verdiğiniz faiz Allah katında artmaz" denilirken asıl kastedilen faizde bir artışın meydana gelmemesi değildir. Herkes bilmektedir ki yapılan borç verme işleminde elbette bir artış oluşmakta fakat bu artış meydana gelmeden sanki meydana gelmiş gibi önceden oranının belirlenmesi farazi bir durumdur. Faraziler üzerine bina edilen bu fazlalığı Allah (cc) tanımamaktadır. Ayrıca verildiği kişi tarafından borcun çalıştırılması sonucunda oluşacak değer farklılaşmasının sadece borçlu lehine olacak şekilde düşünülmesi ve ona bir fazlalığın takdir edilmesi yine Allah (cc) nezdinde reel görülmemektedir. Bunun sebebi ise borç alanın mutlaka kâr edeceğinin varsayılmasıdır. Hâlbuki kârın elde edilip edilmeyeceği, edilse bile miktarının ne kadar olacağının önceden bilinmesi ve belirlenmesi ayette Allah'a savaş açmakla eş değer kabul edilmektedir.

Faizin ekonomide bir artışa sebep olmaması, buna karşın zekâtın artması asIında her iki işlemde bulunan mali akıştan kaynaklanmaktadır. Faizde bu akış ihtiyaç sahibinden zengine doğru olurken, zekâtta zenginden ihtiyaç sahibine doğru olmaktadır.

Faiz içerdiği zararlı işlemler nedeniyle insanları birbirine düşman yapmaktadır. Faiz mağdurları zaman içinde faiz ile zenginleşenlere karşı öfke ile dolmakta ve zamanı geldiğinde bu öfke önü alınmaz sosyal ve siyasal krizlere neden olmaktadır. Zekât ise tam aksine toplum içindeki ekonomik dengesizliği ortadan kaldıran, bireyleri yakınlaştıran ve kucaklaştıran bir rol üstlenmektedir.

Faiz ile karz-ı hasenin ortak noktası her ikisinin de borç verme işlemi olmasıdır. Ayrıldıkları esas nokta ilave kazanç olmaması ve faizde belli bir sürenin şart koşulmasına karşın karz-ı hasen de sürenin şart koşulmamasıdır. Bu, karz-ı hasen' e süre koşulamaz anlamına gelmez. Bilakis karz-ı hasen'e de süre konulabilir ancak şart koşulamaz. Buradan şu sonuca varabiliriz: Faizi haram kılan aslında belirlenen süre değil, o süreye bağlı olarak bir fazlalığın takdir edilmesidir. Üstelik bu fazlalık gelecekte ortaya çıkma intimali olan bir kârın şimdiden ortaya çıkmış gibi kabul edilerek belirlenmesidir.

Karz-ı hasen ile faiz, her ikisi de borç işlemi olmasına rağmen faizin zekât ile kıyaslanması karz-ı hasen'in sürdürülebilir finansman kaynağı olmasındaki endişedir. Zira karz-ı hasen' in bireysel anlamda özellikle insanların ticaret ahlakının bozulduğu dönemlerde sürdürülebilir finansman kaynağı olması zor gözükmektedir. Bu açıdan karz-hasen faaliyetinin kurumsallaşması önem arz etmektedir.

Karz-ı hasen ile faizin karşılaştırılmamasının bir sebebi de karz-ı hasen de borç verenin alacağını geri alamama riski ile faizde borcu verenin alacağını geri alamama riski birbirinden farklıdır. Şöyle ki; karz-ı hasen'de geri verilmeyen borcun telafisi söz konusu değildir ancak faizde çoğu zaman geri alınmakta, faizli işlem yapılanlar arasından birisi borcunu ödemese bile diğerlerinden alınarak telafisi yapılabilmektedir. 
Sonuç olarak; İslam esaslarına dayalı finansman sağlama yollarından zekât ve karz-ı hasen faize alternatif olabilecek iki araçtır. Ancak bu iki araç içinden zekât uygulanabilirlik ve sürdürülebilirlik açısından çok daha iyi bir alternatiftir. Karz-ı hasen ise ancak karşılıksız borç verme bilincinin arttığı, ahde vefa ahlakının yerleştiği ve enflasyonist ortamın ortadan kaldırıldığı toplumlarda faize alternatif olabilir. 


\section{Kaynakça}

Aclûnî, İsmail b. Muhammed. Keşfu'I-hafa ve muzilu'I-ilbas. Beyrut: Şeriketu Şerifi'l-Ensârî, 2000.

Af, Rahoman. Economic Doctrines of Islam. Lahore: Islamic Publications Limited, 1980.

Abdulfettah Muhammed Ferah. et-Tevcihu'I-Istismarî li'z-zekât. İmarat: Duba'I-İslâmî, 1997.

Apaydın, H. Yunus. "Karz". Türkiye Diyanet Vakfı İlam Ansiklopedisi. İstanbul: TDV Yayınları, 2001.

Botticini M. - Eckstein Z. "From Farmers to Merchants: A Human Capital Interpretain of Jewish Economic History". CEPR Discussion Paper 2718, 2003.

Bulaç, Ali. Türkiye'de Zekât Potansiyeli. İstanbul, ISAV Yayınları, ts.

Cezîrî, Abdurrahman. Kitabu'I-Fıkh ala'I-Mezâhibi'I-Erbea. Beyrut: Dâru'l Kütübü'l İlmiyye, 1990.

Demir Osman - Cevahir, Hüseyin. “Türkiye'de Potansiyel Zekât Geliri ve Zekâtın Yoksulluğu Önleyici Rolü" International Journal of Islamic Economics and Finance Studies. 2021/2.

Dihlevi, Şah Veliyyullah. Huccetullahi'l-bâliğa. Çeviri: Mehmet Erdoğan. İstanbul: İz yayıncilık, 1994.

Diwany Tarek. Faiz Sorunu. çev. Mehmet Saraç. İstanbul: İz Yayıncılık, 2011.

Durmuş, Abdullah. “Fıkıhta Karz Sözleşmesinde Vade Şartının Bağlayıcılığı Meselesi”. İslâm Hukuku Araştırmaları Dergisi. 16, 2010, 315-330.

Ergin, Feridun. Para ve Faiz Teorileri. İstanbul: Beta Basım, 1983.

Fîrûzâbâdî, Mecduddin Muhammed bin Yakub. Besairu't-temyiz. ed. Muhammed Ali Neccar. Beyrut: Daru'l-ilmiyye, ts.

Goodson, S.M. A History of Central Banking and the Enslavement of Mankind. London: Black Haouse Publishing, 2014.

Hallo, W.W. God, King, and Man at Yale State and Temple Economy in the Ancient Near East. Leuven: Department Orientalistiek, 1978.

Hammad, Nezih. Akdu'l-karz fi'ş-şeriati'l-Islamiyye. Beyrut: yy., 1991.

İbn Rüşd. Bidayetü'I-müctehid ve nihayetu'I-muktesıd. Beyrut: Dâru'I-Kitabi'I İzzi. İslam Sual ve Cevap, "أحكام التخلص من المال الحر ام بعد التوبة" (Erişim 03.9.2021). https://islamqa.info/ar/ answers/219679

İbn Manzur, Ebi'l-Fadl Cemaleddin Muhammed b. Mukrim. Lisanu'l-arab. Beyrut: Daru'ssadr, 1968.

Illgen, Abdulkadir. "Para-Sermaye ve Emek bağlamında Faiz/Riba Meselesi". Türkiye Günlüğü. 81. Ankara: yy. 2005.

Islahi, Abdulazim. Muhammed Hamidullah: İslam Iktisadının Öncü İsmi, çev. Abdulkadir Macit. Ankara: Iktisat Yayınları, 2019.

Işık, Adem. “ilk Şehirler ve Yazılı Medeniyete Geçiş”. Mavi Atlas. 6 (2) /2018, 29-74.

Kâsânî, Alaaddin Ebu Bekir b. Mesut. Bedâ'i'u's-sanâi' fi tertibi'ş-şerâi'. Beyrut: Daru'lKütübü'I-IImiyye, 1997. 
Kemal Hammad, Nezih. "Tagayyurâtu'n-Nukûd ve'I-Ahkâm el-Müte'allikati bihâ fi'I-Fıkhi'lİslâmî”. Mecelletü'I-Mecmai'l-Fıkhi'l-İslâmî. 1408/1987.

Keynes, John Maynard. The General Theory of Employment, Interest and Money. London: Macmillan Limited, 1970.

Komisyon. Kur'an-ı Kerim ve Türkçe Açıklamalı Meali. Medine: Kral Fehd Mushaf-ı Şerif Basım Kurumu, ts.

Neumark, F. İktisadi Düşünce Tarihi. Çeviri: Ahmet Ali Özeken. İstanbul: iÜ Yayınları, 1983.

Nevevi, Ebu Zekeriyya Yahya b. Şeref. Ravzatu't-Talibin. Tahkik: Adil Ahmed Abdulmevcud, Ali Muhammed Muavvız. Beyrut: Daru'l-Kütüp-i Illmiyye, 1992.

Özdemir, Ahmet. Karz Akdinin Mahiyeti ve Faizli İşlemleri Önleme Fonksiyonu. Çukurova Üniversitesi Ilahiyat Fakültesi Dergisi 12 (1), 125-145.

Özdemir, Mücahit. "Karz-ı Hasen İçin Duyarlılık Artırımalı" (Rpt. Yahya Ayyıldız). IGiAD Bülten. Mayıs, 2019.

Özsoy, İsmail. “Faiz". Türkiye Diyanet Vakfı İslam Ansiklopedisi. İstanbul: TDV Yayınları, 1995.

Rağıp el-İsfehani. el-Müfredat. Daru'I-Marife: Beyrut, 1999.

Razi, Fahreddin. Mefatihu'l-gayb. Beyrut: el-Mektebe et-Ticariyye, ts.

Salih Hamid el-Ulâ. Tevzi'ud-dahl. Dimeşk: Yemâme, 2001.

Saraç, Mehmet. Faiz Teorisini Yeniden Düşünmek. İstanbul: İktisat Yayınları, 2017.

Sırım, Veli. "islam İktisadında Yatırımların Finansmanında Karz-ı Hasen Uygulamaları”. Iğdır Üniversitesi Sosyal Bilimler Dergisi. Ek sayı. (Aralık 2019).

Smith, Adam. The Wealth of Nation. Newyork: Metalibri, 2007.

Smith, W.L. "Monetery theorries of the rate f interest: A dynamic analysis." The Review of Economics and Stattistics. 40 (1), 1958.

Tahmaz, Mahmud. el-Fıkhu'I-Hanefi fi sevbihi'l-cedid. Dımeşk: Dâru'l-kalem, 2014.

Takî el-Osmanî, Muhammed. Buhûs "Ahkâmu'I-Evrâkı'n-Nakdiyye". Dâru'I-Kalem: Dımeşk, 2011.

Ustaoğlu, Murat - İncekara, Ahmet. Faiz Meselesi Tarihte Örnek Uygulamalar. İstanbul: İstanbul Bilgi Üniversitesi Yayınları, 2019.

Vehbe Zuhayli. el-Fıkhu'I-İslâmî. Dimeşk: Dâru'l-fikr, 1989.

Weber, Max. The Protestant Ethic and The Spirit of Capitalism. New York: Charles Scribner's Sons, 1958.

Yavuz, Yunus Vehbi. İslam'da Zekât Müessesesi. Bursa: Feyiz Yayınları, 2008. 
